\title{
Strategies for Improvement of Government Budget Absorption of Bogor City
}

\author{
Gustawan Rachman, Ma'mun Sarma, Dwi Rachmina \\ Kampus IPB Dramaga, Bogor 16680 \\ Kampus IPB Dramaga, Bogor 16680 \\ Kampus IPB Dramaga, Bogor 16680 \\ Email:gustawan@hotmail.com, mamunsarma@yahoo.com dand_rachmina@apps.ipb.ac.id
}

\section{ARTICLE INFO}

Date received : 06 August 2020

Revision date : 02 September 2020

Date received : 10 October 2020

Keywords:

Absorption

Budget Factor

Strategy EFA; $A H P$

\begin{abstract}
This study aims to analyze for factors that cause delays in the absorption of the Bogor City Government's expenditure budget so that a strategy can be formulated to improve the performance of this budget absorption. Searching for variables forming the causal factors is done by using primary data sourced from Dinas Kesehatan and Sekretariat Daerah, based on the researcher's work experience when assigned to the Finance Section and the Planning and Reporting Division of Dinas Kesehatan and Bagian Pengadaan Barang dan Jasa Sekretariat Daerah Kota Bogor for approximately 10 years of the assignment period and library data search. Exploratory Factor Analysis (EFA) is used to look for underlying factors extracted from the factors forming variables. The search for alternative strategies to improve performance of budget absorption was carried out using the Analytic Hierarchy Process (AHP). The EFA analysis found five main factors causing delays in the absorption of budget expenditure, namely factor in budget planning activities, factor in government regulation and bureaucracy, factor of work conditions, factor influencing financial activities and disbursement of the Government budget, and human resources of the state civil apparatus (ASN). AHP analysis shows that of the five leading sectors of the Regional Apparatus that play a role as key leaders in improving the performance of budget absorption is Sekretariat Daerah. The main obstacle in improving budget absorption is internal and external intervention. The main strategy to correct delays in spending is to improve quality of budget planning and procurement of service goods.
\end{abstract}

\section{INTRODUCTION}

The Bogor City Government still has problems in the absorption performance of the budget because of two things. First, based on the data of the Local Government Budget Realization Report (Ministry of Finance 2020), the average absorption of bogor city government budget for the period 2010 to 2018 is generally lower than the average absorption of other local government budgets (districts and cities) in West Java Province (Figure 1). 


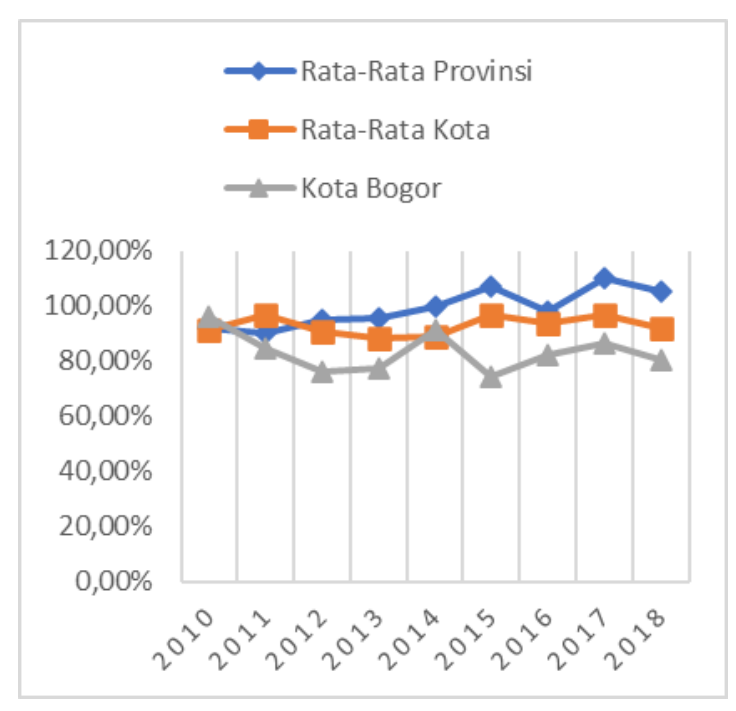

Source : \{Formatting Citation\}

Figure 1: Comparison of the achievement of the absorption of bogor budget and the total province of West Java

Second, if the budget and realization are breakdown by month from the data of 2016 to 2018 , there is an overview of the absorption performance of bogor city budget which is always slower than the schedule already compiled (figure 2). This indicates a gap in budget absorption throughout the year. Absorption was highest in july, except for 2018.

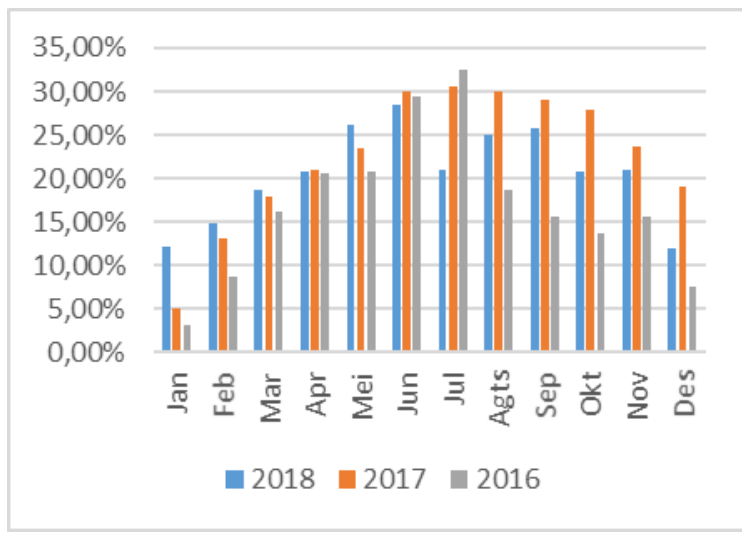

Source: [TEPRA] Budget Realization Evaluation and Supervision Team (2018) Figure 2: Budget absorption gap between plan and realization of 2016, 2017 and 2018 at Bogor City Government

The research will begin with the collection of variables causing delays in the absorption of the Bogor City Government's budget, then reducing them to several underlying contributing factors. After that, a strategy or activity program is devised to improve it. Therefore, the main purpose of this study is to find strategies for improving budget absorption in Bogor City Government.

Before formulating an improvement strategy is necessary information on the factors that are the cause of the delay in budget absorption which is then reduced to several main factors. Therefore, the first question that wants to be answered from this study is "What factors are causing the delay in the absorption of the budget in bogor city government?"

Once the factors affecting budget absorption performance are known, a strategy can be devised and used as an activity program to improve it. Therefore, the second thing to answer from this study is that "What startegi can be proposed to improve the absorption performance of the budget in bogor city government?"

Based on the above background, the purpose of this study can be explained as follows:

1. Analyzing the main factors causing delays in the absorption of the budget in bogor city government;

2. Strategize to improve the delay in the absorption of the budget in bogor city government.

\section{METODE}

Delays in the absorption of government budgets led to the slow implementation of activities or programs, delays in disbursement of funds, and the build-up of bills to the Government at the end of the fiscal year (Setyawan, 2017). Therefore, efforts to improve the delay in the absorption of bogor city government budget should be carried out. An overview of the frame of mind is shown in Figure 3.

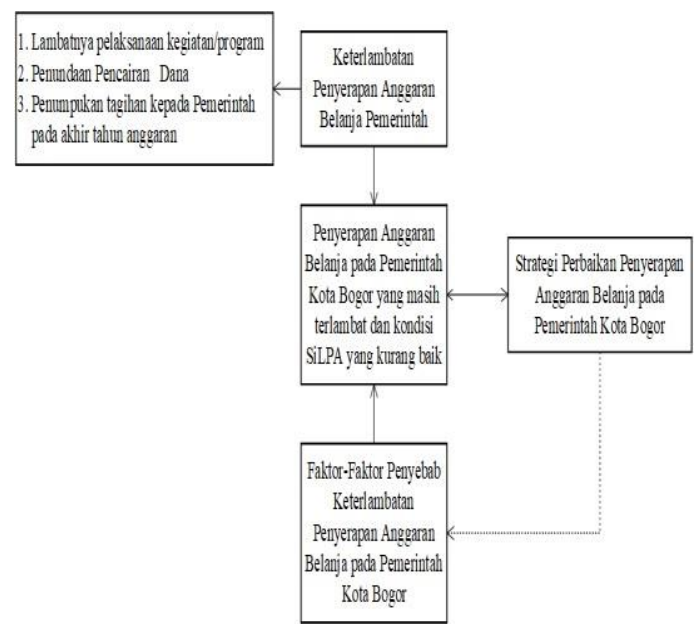

Figure 3: Research thought framework

This research was conducted in Bogor city from April to June 2020. The object of his research is the Bogor City Government. This lokus election is based on the consideration that there is always a delay in the absorption of bogor city government budget every year. This research is expected to be one of the inputs to improve the absorption performance of the budget in bogor city government. 
For the purposes of this research, information is collected to cause delays in budget absorption from primary data and secondary data. Secondary data information is obtained from the results of (Herriyanto H, 2012) and (Febrianti, 2015). Primary data information is sourced from the Department of Health and Regional Secretariat, based on the work experience of researchers when assigned to the Finance And Planning and Reporting Department of the Bogor City Health Office and the Procurement Department of Goods and Services of the Bogor Regional Secretariat for approximately 10 years of assignment period. Primary data from respondents was collected using research questionnaire instruments. Secondary data as a support is obtained from financial data from the Development and Procurement Administration department of the Regional Secretariat of Bogor, the Budget Realization Evaluation and Supervision Team (TEPRA), and the Ministry of Finance of the Republic of Indonesia. presented descriptively.

The study used efa analysis methods to look for underlying factors causing budget delays from causal variables collected with observation and library studies, and AHP methods for strategy search. Efa analysis was conducted with data collection conducted by filling out questionnaires by 168 respondents from all 36 Regional Devices. As for the AHP method, a shortlist of respondents has filled out the EFA analysis questionnaire. Respondents to the AHP analysis consisted of 13 respondents from the 3rd echelon of 7 people, echelon 4 for 2 people, a monev team of 1 person, and a procurement official of 3 people. The statements are compiled to obtain data that shows a description of each variable. The variable measurement method used using the Likert Scale which is an attitude measurement method by expressing its agree or disapproval of a particular subject or object withscoring system in the criteria of grade 1 for Strongly Disagree (STS) up to a value of 5 for Strongly Agree (SS). Primary data is processed using EFA analysis and AHP analysis. The criteria for filling out the questionnaire are the State Civil Apparatus (ASN) which holds the position of Budget User/Budget User Power (PA/KPA), Commitment Making Officer (PPK), Procurement Officer (PP), Technical Implementation Officer of Activities (PPTK) or PPTK Staff and Regional Monev Team.

This research uses two analytical methods, namely (1) efa analysis method to look for underlying factors causing budget delays, and (2) AHP methods to formulate budget absorption improvement strategies. In the EFA analysis, the first step is to identify the variables that cause the delay in budget absorption. The collected data is then tested for reality and validity. Instruments are considered realibels if the measured reliability coefficient value using Cronbach's Alpha is a measuring instrument to measure data consistentity if repeated measurements will produce output equal to the target value greater than 0.60 (Sujarweni 2014). While the validity test compares between $r$ count and $r$-table with a certain number of $n$ and a certain confidence level. 58 question items will be tested. With the number of samples or $\mathrm{N}$ analyzed is a total of 168 samples. The validation process was assisted by jamovi statistics computer program with a significance rate of $95 \%(\alpha=5 \%)$ and $\mathrm{df}=168-2$ $=166$, then compared between $r$ count and $r$ table where if $r$ count $>r$ table then the questionnaire item is valid, if otherwise invalid.

The next step is to test the feasibility of data conducted several tests, namely (1) Kaiser Meyer Olkin Test (KMO) Measure of Sampling Adequacy which is a tool to measure sampling adequacy for each variable; (2) Bartlett Test of Sphericity is an instrument to test the matrix of factors that form whether the matrix of identity or not, and the MSA value of the diagonal value of the anti-image correlation matrix indicates how strongly one item correlates with another item with its cut-off is $>0.50$.EFA analysis is a multivariate statistical method for reducing data and lifting hidden relationships between variables that form the foundation concept of an unknown state (Heir et al. 2014).

After efa analysis, continued with ahp analysis (analytical hierarchy process) to look for alternative strategies for improving budget absorption of Bogor City Government. AHP analysis uses human perception as its input (Saaty 1994). The hierarchy structure for this study is shown in Figure 4.

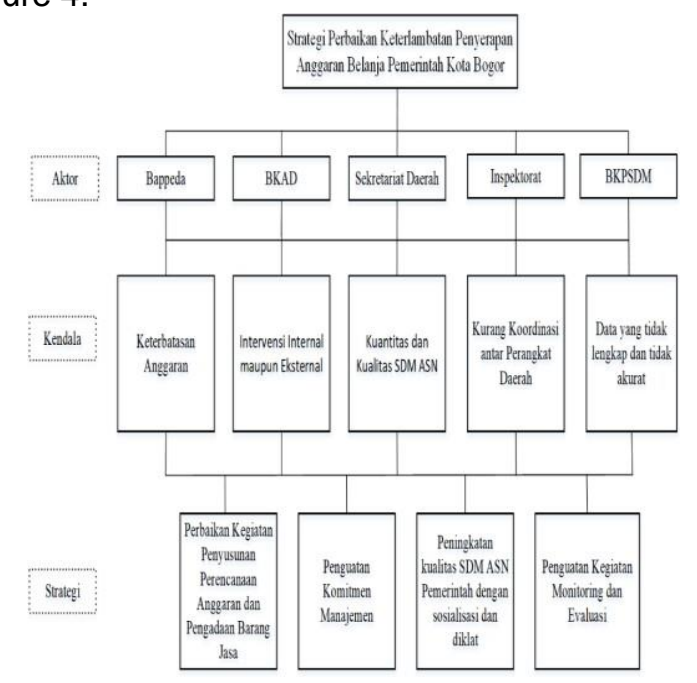

Figure 4. Hierarchy structure formulamation strategy for improvement of Budget absorption 


\section{RESULTS AND DISCUSSION \\ Analyse des facteurs causant des retards d'absorption budgétaire}

Based on the research has been identified there are 6 potential factors causing the delay in budget absorption namely (1) Activity Planning activities and budget preparation, (2) Procurement activities of goods and services, (3) Human resources problems of the State Civil Apparatus (ASN), (4) regulatory and bureaucratic barriers, (5) treasurer factors and financial activities, and (6) other factors. These six factors can be broken down into the following 58 variables and their variable codes:

1. Activity Planning and Budgeting Activities (Code P1-P10)

1) Planning activities not according to needs (P1);

2) Duplication of activities between Regional Devices (P2);

3) Preparation of budget ceiling is too low from market price (P3);

4) Completeness and suitability of data as a budget preparation material (P4);

5) The duration of the budget planning time until it is determined to be a Budget Implementation Document (DPA) (P5);

6) There is a Work Plan and Budget (RKA) and a General Procurement Plan (GM) that is still not in accordance with (P6);

7) An error in the determination of the budget account code (P7);

8) Level of effectiveness of RKA DPA assistant activities (P8);

9) RKA/DPA late set (P9);

10) Activities have not been included in the Regional Property Needs Plan (RKBMD) (P10).

2. Procurement activities of Goods and Services (BJP Code 1- PBJ19);

1) There was an error in the selection of procurement methods of goods and services (PBJ1);

2) Incorrect/incomplete activity Framework (KAK) (PBJ2);

3) Procurement schedule that does not comply with the planning schedule (PBJ3);

4) The AGM is too late to be input and announced (PBJ4);

5) The difficulty in determining the SelfEstimated Price (HPS) and HPS is not determined by expertise and not through market surveys (PBJ5);

6) The scope of responsibility of the Commitment Making Officer (PPK) in starting the process of procurement of goods and services (PBJ6);

7) The time it takes for the repair of KAK and HPS from PPK (PBJ7); Procurement activities delayed due to internal policy of Regional Devices (PBJ8);

8) Procurement activities are delayed due to external influence on PPTK and PPK from outside the Regional Device (PBJ9);

9) The procurement process is hampered due to external influence on the independence of the Electoral Office or Procurement Officer (PBJ10);

10) Activities delayed due to procurement process must be repeated due to tender failure (PBJ11);

11) The Contract Addendum due to Contract Change Order (CCO) or other causes (PBJ12);

12) Specifications of goods/materials are not available/hard to come by (BJP13);

13) Late completion of the agreed contract schedule (PBJ14));

14) The Provider does not take a down payment or slow in filing a payment bill (PBJ15);

15) The selected provider failed to complete the Work (BJP 16);

16) Difficulty in coordinating and supervising between the event manager and the provider in the implementation of activities /projects (PBJ17);

17) The number of ASN procurement implementers who pass the certification of procurement of government goods and services is inadequate (PBJ18); The absence of functional procurement positions on technical regional devices and those with a relatively large budget portion (PBJ19).

3. Human resources issues of the State Civil Apparatus (Code ASN1 - ASN10):

1) Culture/working habits of $A S N$ in government systems and environments (ASN1);

2) Number of activities/assignments handled by an ASN (ASN2);

3) Asn's busyness in drafting the Letter of Accountability (SPJ) (ASN3);

4) The number of ASNs is still less than needed (ASN4);

5) Reward and punishment mechanism for ASN (ASN5);

6) Training activities to improve asn skills and quality (ASN6);

7) Rotation / displacement / mutation of staff too fast / sudden (ASN7);

8) Incomplete/incomplete handover process (ASN8);

9) ASN placement based on skills and experience or educational background (ASN9);

10) Level of understanding of the Technical Implementation Officer of Activities (PPTK) towards the activities to which it is responsible (ASN10). 
4. Regulatory barriers and government bureaucracy (Code R1 - R7)

1) Government regulation in the field of budget planning and overlapping financial management (R1);

2) Government Regulations in the field of procurement of government goods and services that spill overlapped (R2);

3) Lack of socialization activities implementing Government Regulation in the field of budget planning and financial management (R3);

4) Lack of socialization activities in the implementation of Government Regulation in the field of procurement of Government goods and services (R4);

5) Asn's level of understanding of Government Regulation related to budget planning and financial management activities (R5);

6) Asn's level of understanding of Government Regulations related to government procurement activities (R6);

7) Conformity between the procurement process of goods and services is carried out with government regulations (R7).

5. Treasurer factors and financial activities (Code K1-K6)

1) Errors or incompleteness in the disbursement submission document to the Regional Treasurer (K1);

2) The process of reimbursement of inventory /replace money supply /add money supply (UP/GU/TU) in The Treasurer expenditure (K2);

3) Discrepancies between the schedule of activities and the cash disbursement schedule (K3);

4) Revised activities should wait for the schedule of changes in the annual budget (ABT) (K4);

5) Additional ceiling due to previously unexpected ABT by PPTK (K5);

6) Waiting time for receipt of incoming transfers to Regional Coffers from the Central/Provincial Government for activities whose budgets are sourced from special allocation funds (DAK) or provincial assistance (Banprov) (K6).

6. Other factors (Code L1-L6)

1) The power majeur: natural disasters or social problems (L1);

2) Weather/climate factors that hinder the completion of activities (L2);

3) Adjustment of the Government's work environment to technological advancement (L3);

4) adequate availability of infrastructure/work facilities (L4);

5) ASN's reluctance to engage in procurement activities of goods and services due to the risk of entangled legal cases (L5);
6) Management support factor (L6).

Based on the results of reliability testing, the resulting Cronbach's Alpha coefficient value of all question items of 0.934 is greater than 0.60 indicating the instrument with 58 question items declared reliabel. Validity tests show there are 2 invalid question items, namely the data completeness and conformity variable as a budgetmaking material (P4) and a variable level of effectiveness of RKA DPA (P8) assistant activity because it has a calculated $r$ value ( $P 4=0.118$ and $P 8=0.128)$ that is smaller than the $r$ table $(0.151)$. Furthermore, the variables were further analyzed by 56 varibels.

The next step is to test the feasibility of whether factor analysis is necessary through testing Kaiser Meyer Olkin (KMO) Measure of Sampling Adequacy And Bartlett Test of Sphericity. From the test results of 56 question items, a value is generated (KMO) Measure of Sampling Adequacy overall amount of $0,821 \quad(>0,5)$ and Bartlett Test of Sphericity as big as $0,001(<0,005)$, so it is feasible to do further factor analysis. Other tests were conducted with anti-image matrices correlation by looking at the value of the measure sampling adequacy (MSA). From the test results of 56 questionnaire/variable items, all escaped because they had a value of $>0,50$.

The next step is to determine the number of factors formed using EFA analysis, and oblimin rotation using parallel analysis methods. Loading factor required is a minimum of 0.430 for 168 samples (Heir et al. 2014). Varibels that have a loading factor value of less than 0.430 could not be further analyzed in the EFA analysis. Based on these criteria, the resulting factors cause budget absorption delays of 29 variables calcified into 5 groups of factors as seen in Table 1. The first factor is the analysis output representing $16.13 \%$ of the total accumulative variant consisting of 10 variables with P7 having the highest loading (0.772) and P3 having the lowest loading (0.503). The second factor represents $9.07 \%$ of the total accumulative variant consisting of 4 variables with $\mathrm{R} 6$ having the highest loading (0.900) and ASN9 with the lowest loading $(0.482)$. The third factor represents $8.01 \%$ of the total accumulative variant consisting of 6 variables with PBJ12 having the highest loading (0.652) and ASN10 getting the lowest loading (0.442). The fourth factor represents $7.15 \%$ of the total accumulative variant consisting of 5 variables with ASN3 having the highest loading (0.629) and R3 getting the lowest loading (0.439). The fifth factor represents $6.19 \%$ of the total accumulative variant consisting of 4 variables with $\mathrm{K} 5$ obtaining the highest loading (0.674) and K1 obtaining the lowest loading (0.485). 
Table 1.

Tabel loading factor with Oblimin rotation

\begin{tabular}{|c|c|c|c|c|c|c|c|c|c|}
\hline \multicolumn{2}{|c|}{$\begin{array}{c}\text { Factor } \\
1\end{array}$} & \multicolumn{2}{|c|}{$\begin{array}{c}\text { Factor } \\
2\end{array}$} & \multicolumn{2}{|c|}{ Factor 3} & \multicolumn{2}{|c|}{ Factor 4} & \multicolumn{2}{|c|}{$\begin{array}{c}\text { Factor } \\
5\end{array}$} \\
\hline P7 & $\begin{array}{l}7 \\
7 \\
2 \\
\end{array}$ & R6 & $\begin{array}{l}9 \\
0 \\
0 \\
\end{array}$ & PBJ12 & $\begin{array}{l}6 \\
5 \\
2 \\
\end{array}$ & ASN3 & $\begin{array}{l}6 \\
2 \\
9 \\
\end{array}$ & K5 & $\begin{array}{l}0 \\
\dot{6} \\
7 \\
4 \\
\end{array}$ \\
\hline PBJ2 & $\begin{array}{l}7 \\
6 \\
8 \\
\end{array}$ & R5 & $\begin{array}{l}8 \\
7 \\
3 \\
\end{array}$ & PBJ11 & $\begin{array}{l}6 \\
2 \\
9 \\
\end{array}$ & L5 & $\begin{array}{l}5 \\
5 \\
3 \\
\end{array}$ & K4 & $\begin{array}{l}0 \\
\dot{6} \\
5 \\
0\end{array}$ \\
\hline PBJ1 & $\begin{array}{l}0 \\
5 \\
7 \\
1 \\
3 \\
\end{array}$ & R7 & $\begin{array}{l}0 \\
. \\
5 \\
9 \\
7 \\
\end{array}$ & L1 & $\begin{array}{l}6 \\
2 \\
5 \\
\end{array}$ & ASN8 & $\begin{array}{l}0 \\
5 \\
5 \\
3 \\
9\end{array}$ & K3 & $\begin{array}{l}0 \\
4 \\
8 \\
8 \\
8\end{array}$ \\
\hline P2 & $\begin{array}{l}0 \\
6 \\
6 \\
6 \\
8 \\
\end{array}$ & $\begin{array}{l}\text { ASN } \\
9\end{array}$ & $\begin{array}{l}0 \\
. \\
4 \\
8 \\
2 \\
\end{array}$ & L2 & $\begin{array}{l}6 \\
0 \\
5 \\
\end{array}$ & ASN2 & $\begin{array}{l}0 \\
5 \\
5 \\
2 \\
0 \\
\end{array}$ & K1 & $\begin{array}{l}0 \\
4 \\
4 \\
8 \\
5\end{array}$ \\
\hline P6 & $\begin{array}{l}0 \\
. \\
6 \\
5 \\
9\end{array}$ & & & P5 & $\begin{array}{l}0 \\
4 \\
6 \\
6\end{array}$ & $\mathrm{R} 3$ & $\begin{array}{l}0 \\
4 \\
3 \\
9 \\
\end{array}$ & & \\
\hline PBJ3 & $\begin{array}{l}0 \\
6 \\
6 \\
5 \\
8\end{array}$ & & & ASN10 & $\begin{array}{l}0 \\
4 \\
4 \\
2\end{array}$ & & & & \\
\hline PBJ5 & $\begin{array}{l}5 \\
6 \\
5 \\
\end{array}$ & & & & & & & & \\
\hline P10 & $\begin{array}{l}5 \\
2 \\
1\end{array}$ & & & & & & & & \\
\hline P1 & $\begin{array}{l}5 \\
0 \\
7 \\
\end{array}$ & & & & & & & & \\
\hline P3 & $\begin{array}{l}5 \\
0 \\
3 \\
\end{array}$ & & & & & & & & \\
\hline
\end{tabular}

Note:

Factor 1 : Budget Planning Activity

Factor 2 : Regulatory Barriers factor and Government Bureaucracy

Factor 3 : Working Condition

Factor 4 : Human Resources Factor ASN

Factor 5 : Treasurer factor and Financial Activities

To see the model-of-fit match for the model already produced, judging by the average difference per degree of freedom expected to occur in the population or RMSEA (Root Mean Square Error of
Approximation). RMSEA $<0.08$ is good fit (Wijanto 2008), statistical calculation result, RMSEA $=0.0681<0.08$, RMSEA with $90 \%$

confidence interval $(\mathrm{Cl})$, lower limit value 0.0501 and upper limit value 0.0728 . RMSEA $=0.0681$ is between the lower limit and the upper limit. These results show good fit or match of the resulting model and meet statistically. After that, the factors named, and the cause of the delay in the budget absorption of the Bogor City Government can be explained by 5 fundamental factors namely:

1. Budget Planning Activity Factors

Based on the results of the analysis, there are 10 variables that form the factor of budget planning activities namely (1) the error in the determination of the shopping account code (P7), (2) the framework of the wrong/incomplete activity reference (PBJ2), (3) the selection of procurement methods of goods and services (PBJ1), (4) the duplication of activities between Regional Devices (P2), (5) the implementation plan and budget (RKA) and the General Procurement Plan (GM) which are still not in accordance with (P6), (6) the schedule of implementation procurement that is not in accordance with the planning schedule (PBJ3), (7) difficulty in determining the estimated price itself (HPS) and HPS is not determined based on expertise and not through market surveys (PBJ5), (8) activities have not been included in the Regional Goods Needs Plan (RKBMD) (P10), (9) planning activities not in accordance with the needs (P1), and (10) the preparation of budget ceilings is too low than the market price (P3).

2. Regulatory Barriers and Government Bureaucracy Factors

Based on the results of the analysis, there are 4 questionnaire items that form the factors of regulatory and bureaucratic obstacles of the Government namely (1) asn level of understanding of Government regulations related to government procurement activities (R6), (2) asn level of understanding of Government Regulations related to budget planning and financial management activities (R5), (3) conformity between the procurement process of goods and services implemented with Government regulation (R7), and (4) asn placement based on skills and experience or educational background (ASN 9) .

3. Working Conditions Factor

Based on the results of the analysis, there are 5 questionnaire items that form the factor of working conditions namely the absence of contract addendum due to Contract Change Order (CCO) or other causes (PBJ12), activities that are delayed because the procurement process must be repeated due to failed tender (PBJ11), the absence of force majeur: natural 
disaster or social problems (L1), weather/climate factors that impede the completion of activities (L2), the duration of the budget planning time until it is determined to be a Budget Implementation Document (DPA) (P5), and the level of understanding of the Technical Implementation Officer of Activities (PPTK) on the activities to which it is responsible (ASN10).

4. ASN Human Resources Factor

Based on the results of the analysis, there are 5 questionnaire items that form the influence factor of financial activities and disbursement of government budgets, namely the busyness of ASN in Compiling The Letter of Accountability (SPJ) (ASN3), asn reluctance to engage in procurement activities of goods and services due to the risk of getting entangled in legal cases (L5), the process of handing over incomplete or incomplete positions (ASN8), the number of activities or assignments handled by an ASN (ASN2), and the lack of socialization activities in the implementation of Government Regulations in the field of planning and finance (R3).

5. Treasurer And Financial Activities Factors

Based on the results of the analysis, there are 4 questionnaire items that form the influence factor of financial activities and disbursement of government budget, namely the addition of ceiling due to the previously unexpected annual budget (ABT) by PPTK (K5), revised activities must wait for the schedule of changes $A B T$ (K4), discrepancy between the schedule of implementation of activities and cash disbursement schedule (K3), and errors or incompleteness in the disbursement submission document to the Regional Treasurer (K1).

Strategies for Improving The Absorption Of Budget Absorption in Bogor City Government

Once the factors causing the delay in the absorption of the budget are known, the next step is to find alternative strategies to improve the absorption performance of the Bogor City Government's budget through ahp analysis. Based on ahp analysis can be shown the value of each component for each level of hierarchy which includes regional devices as leading sectors or key leaders, obstacles encountered, and alternative strategies that are a priority (Pictured 5).

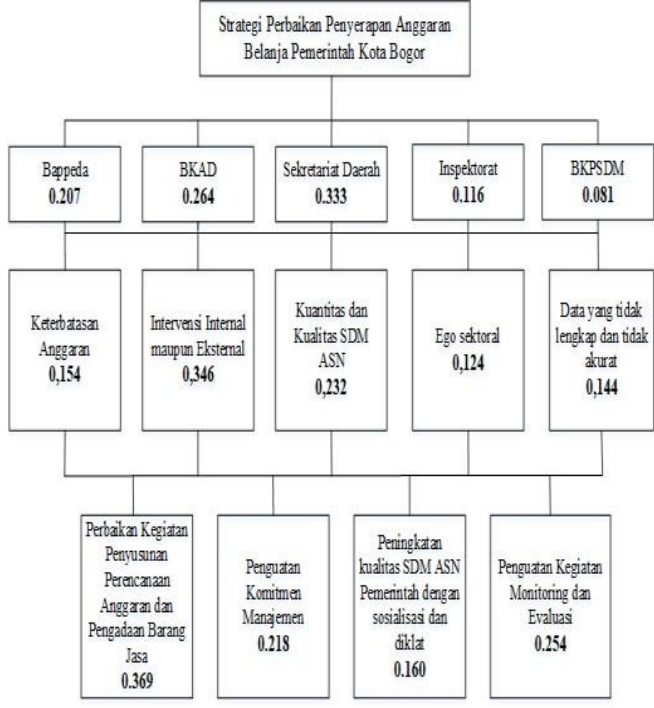

Figure 5. AHP analysis formulation of strategy to improve the absorption of bogor city budget

1. Leading Sector Regional Devices

The leading regional device sector and is a key leader in efforts to improve budget absorption performance is the Regional Secretariat with a score of 0.333 , then BKAD score 0.264, Bappeda score 0.207, Regional Inspectorate score 0.116, and Human Resources Management and Development Agency (BKPSDM) score 0.081. This shows the Regional Secretary plays a key role in improving the absorption performance of this budget.

2. Constraints

The main obstacles in efforts to improve the absorption of bogor city budget are internal and external intervention with a score of 0.346 , then quantity and quality of SDM ASN score of 0.232 , budget limitation of 0.154 , incomplete and inaccurate data score of 0.144 , and sectoral ego score of 0.124 . That is, to improve the absorption performance of bogor city government budget is necessary improvement in terms of internal and external interventions.

3. Strategy

The results of ahp calculation show that based on the relationship of leading sector variables with strategy and also considering constraints, priority strategy to improve the absorption performance of anggara in Bogor City Government namely improving the quality of budget planning activities and procurement of service goods (score of 0.369). Other strategies on the next priority are strengthening monitoring and evaluation activities (score of 0.254), strengthening management commitment (score of 0.218), and improving the quality of ASN Bogor City with certification and training (score scoring 0.160). 


\section{Preparation of Activity Program}

After the budget absorption improvement strategy is selected, it is necessary to set up an activity program in order for the budget absorption improvement strategy to be truly implemented. The main strategy that is a priority is the strategy of improving budgeting and procurement of goods and services. The relevant program for the implementation of the strategy is reform of the preparation of budget planning. The reform program for the preparation of the budget planning can consist of several activities, namely the Establishment of a Reform Management Team for the Preparation of Regional Budget Planning. The Regional Devices responsible for this program are the Regional Secretary, BKAD, Bappeda, and the Regional Inspectorate. The proposed program is based on the fact that budget planning activities are a routine activity that is carried out everys, but with the same results from year to year. This means that there needs to be a fundamental change to the bogor city government's budget planning activities. For this, a team needs to be formed to be able to develop a clear road map in order to reform the budget planning in order to achieve optimal improvement goals.

An alternative strategy to choose from is to improve the quality of ASN Bogor city with certification and training. The program of activities that can be proposed to realize the so-called human resources quality improvement program with ASN Quality and Capability Improvement activities in Mastery of Planning Management and Budget Usage. Regional devices that can be expected to be active are BKPSDM, BKAD and Bappeda. This program is proposed based on the results of efa analysis which shows that one of the contributing factors of budget absorption delay is asn human resources factor, so there should be activities that can improve the quality of ASN especially related to the mastery of planning management and budget usage because on this side is one of the weak points of ASN based on the results of the analysis. Shown in Table 2.

Table 2.

Program design and performance improvement activities of Bogor City Budget absorption

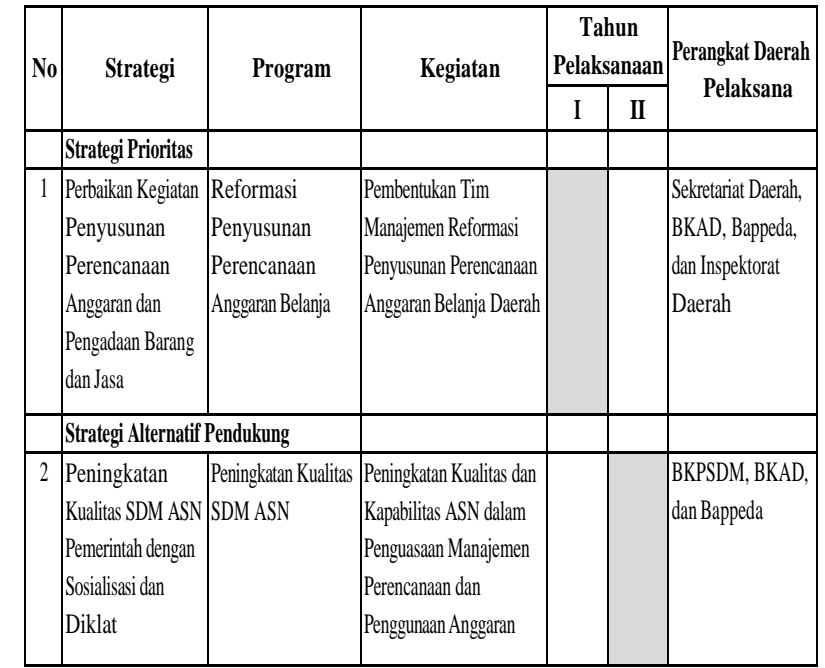

Description:

$>$ BKAD : Regional Financial Entities and Assets (Badan Keuangan dan Aset Daerah)

$>$ Bappeda : Regional Planning and Development Agency (Badan Perencanaan dan Pembangunan Daerah)

$>$ BKPSDM : Human Resources Staffing and Development Agency (Badan Kepegawaian dan Pengembangan Sumber Daya Manusia)

$>$ SDM ASN : Human Resources of the State Civil Apparatus (Sumber Daya Manusia Aparatur Sipil Negara)

\section{CONCLUSION}

Based on the results of the research that has been carried out, it can be concluded as follows:

There are five factors that cause delays in the absorption of bogor city budget, namely budget planning factors, especially related to the procurement of goods and services, regulatory and bureaucratic barriers factor, working conditions factor, ASN human resources factor, and influence factor of financial activities and disbursement of government budget;

The main priority strategy to improve the absorption performance of bogor city government budget is to improve the quality of budget planning and procurement activities of service goods, and the alternative supporting strategy is to improve the quality of ASN human resources. The Regional Secretariat as a key leader in the leading sector is expected to be the priority strategy coordinator, and BKPSDM becomes a coordinator on alternative support strategies. The main potential obstacles in the implementation of budget absorption improvement efforts are internal and external interventions. 


\section{REFERENCES}

Febrianti D. 2015. Analisis Faktor-Faktor yang Mempengaruhi Rendahnya Penyerapan Anggaran Proyek pada Badan Pengembangan Wilayah Suramadu. Tesis. Surabaya (ID): Institut Teknologi Sepuluh Nopember.

Heir JF, Black WC, Babin BJ, Anderson RE. 2014. Multivariate Data Analysis. $7^{\text {th }}$ Edition. Harlow: Pearson Education Limited.

Herriyanto H. 2012. Faktor-Faktor yang Mempengaruhi Keterlambatan Penyerapan Anggaran Belanja pada Satuan Kerja Kementerian/Lembaga di Wilayah Jakarta. Tesis. Jakarta (ID): Universitas Indonesia.

[Kemenkeu] Kementerian Keuangan. 2020. Deskripsi dan Analisis APBD [internet]. [diacu diacu 2020 Juli 08]. Tersedia dari: http://www.djpk.kemenkeu.go.id/visual/\#/.

Mankiw NG. 2012. Principles of Macro Economics. $6^{\text {th }}$ Edition. South-wetan: Cengage Learning.

Miliasih. 2012. Analisis Keterlambatan Penyerapan Anggaran Belanja Satuan Kerja Kementerian/Lembaga TA 2010 di Wilayah Pembayaran KPPN Pekanbaru. Tesis. Jakarta (ID): Universitas Indonesia.

Saaty TL. 1994. Fundamentals of Decision Making and Priority Theory with Analytical Hyrarchy Process. Pittsburgh (USA): RWS Publications.
Sujarweni VW. 2014. Metode Penelitian: Lengkap, Praktis, dan Mudah Dipahami. Yogyakarta: Pustaka Baru Press.

[TEPRA] Tim Evaluasi dan Pengawasan Realisasi Anggaran. 2018. Profil Pemanfaatan Monev oleh K/L/D/l [internet]. [diakses 2018 Desember 31]. Tersedia dari: http://www.monev.lkpp.go.id.

Wijanto S. 2008. Structural Equation Modelling dengan Lisrel 8.8. Graha IImu, Yogyakarta

\section{BIBLIOGRAFI}

Febrianti, Diana. (2015). Analisis Faktor-Faktor Yang Mempengaruhi Rendahnya Penyerapan Anggaran Proyek Pada Badan Pengembangan Wilayah Suramadu. Institut Teknologi Sepuluh Nopember.

Herriyanto H. (2012). Faktor-Faktor yang Mempengaruhi Keterlambatan Penyerapan Anggaran Belanja pada Satuan Kerja Kementerian/Lembaga di Wilayah Jakarta. Tesis. Jakarta (ID): Universitas Indonesia.

Rachman, Gustawan, \& Rachmina, Dwi. (n.d.). Strategies for Improvement of Government Budget Absorption of Bogor City. JURNAL MANAJEMEN AGRIBISNIS (Journal Of Agribusiness Management), 8(2), 207-219.

Setyawan, Adi. (2017). Analisis Keterlambatan Penyerapan Anggaran Belanja Satuan Kerja Kementerian/Lembaga di Wilayah Pembayaran KPPN Bojonegoro Tahun Anggaran 2015. UNIVERSITAS AIRLANGGA.

\section{Copyright holder:}

Gustawan Rachman, Ma'mun Sarma, Dwi Rachmina (2020)

First publication right :

Journal of Social Science

This article is licensed under:

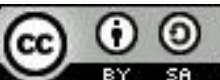

